\title{
Investigating the Relationship between Organizational Dissent and Life Satisfaction
}

\author{
Abidin Dağlı \\ Department of Educational Sciences, Dicle University, Turkey
}

Copyright $(2017$ by authors, all rights reserved. Authors agree that this article remains permanently open access under the terms of the Creative Commons Attribution License 4.0 International License

\begin{abstract}
The aim of this study is to investigate the relationship between organizational dissent and life satisfaction perceptions of public primary school teachers. This research is a descriptive study in relational survey model. The sample consists of randomly chosen 200 primary school teachers who are working in Diyarbakir city center during the 2013-2014 academic year. "Organizational Dissent Scale" which is developed by Kassing (2000) and adapted from English to Turkish by Dağlı (2015) and "Life Satisfaction Scale" developed by Diener, Emmons, Larsen and Griffin (1985) and adapted from English to Turkish by Dağlı and Baysal (2016) were used for collecting data. As for the results of the research, it is found that according to the gender there is significant difference in the dimension of "upward dissent" and for the union membership, monthly income significant difference was found in "lateral dissent" dimension among the perceptions of teachers. Another finding of the study is that teachers are dissenting "highly" in "upward" and "lateral" dissent dimensions and there is a significant, low, negative relationship between teachers' dissent and life satisfaction perceptions $[\mathrm{r}=-, 181(\mathrm{p}=0,010)]$.
\end{abstract}

Keywords Organizational Dissent, Upward Dissent, Lateral Dissent, Life Satisfaction, Primary School Teacher

\section{Introduction}

Dissent is defined as "being against an attitude, idea or behavior" [1]. Dissent occurs when a triggering event is beyond an individual's endurance limits [2]. Although there are many definitions available in literature, the outstanding features can be grouped into five titles. These are; (i) the dissent arise as a result of dissatisfaction with current situation, (ii) when someone has opposite views with status quo and has to take a defending position, (iii) when overt protesting and opposition is needed, (iv) someone has hostile feelings, (v) mainly comprise of principle related issues [3]. Individuals can dissent to managers for their decisions and practices of management. Dissent has an important role for protecting the individual rights and freedom as long as it doesn't contain violence and destructive insult. It can occur when the ideal manager features are non-existent [4].

Redding [2] argues that the dissent can stem from many sources. The most important of these is the poorly given decisions of the organization's managers. Those decisions can be unethical or against the law as well as being unproductive, useless or in a manner which teases the members. Hegstrom [5] denotes that the duties, responsibilities of the members and discrimination for some individuals can cause dissent in organizations.

Organizational dissent is defined as voicing the opposite views and conflicts within organization [3]. Defined as the explaining the opposite views or disagreement with the organizations' practices or policies, organizational dissent starts with a triggering event [6,3].This triggering event forces the members to explain and share their counter views regarding the system and policies [7]. Before voicing the displeasure members of the organization need to perceive the problem and they need to treat it as worth intervening [6]. Organizational dissent is also very important with regard that it contributes to the development of democracy within organization besides discussing the problems which are likely to occur [8].

Kassing [9] determined the sub-dimensions of organizational dissent which are (1) upward/upward dissent, (2) lateral/lateral dissent, (3) displaced dissent. These dimensions will be explained briefly in the following paragraphs.

1. Upward/Upward Dissent: It occurs when the members of the organization explain their opposing views to the individuals which can affect the power relations in organization. Upward dissent includes expressing disagreement or contradictory opinions to the managers directly $[9,8,10,11,12,13]$.

2. Lateral Dissent: It occurs when employees express disagreement or contradictory opinions to their co-workers who have no role in power relations in organization [9].

3. Displaced Dissent: This kind of dissent emerges when 
the members of the organization express disagreement with non-work friends, family and partners $[3,9,14]$.

Life satisfaction is one of the main factors for people to be happy and makes sense of life. It attracted attention of researchers for many years. Life satisfaction defined as a case or conclusion which someone draws by comparing the expectations with the ones he/she has in life [15], a positive evaluation of his life according to the self-determined criteria and an important factor for a comprehensive happiness [16], a sum of all his faith and judgments about life or general attitude about his life [17]. Shin and Johnson (1978) define life satisfaction as an individual's self-evaluation of life based on his own standards. It can also be defined as the degree of positive development in life quality as a whole [18].

Being satisfied with life is not limited to a certain part of life but rather it is a comprehensive positive evaluation of life, so being happy with the job does not upward that the person is happy with the life. Job satisfaction can foster life satisfaction but cannot replace it. The object of life satisfaction is all area of life [19]. When the positive judgments of an individual regarding the life are higher than the negative ones it shows that the person's life quality is high [20]. Diener [21] denotes that life satisfaction has a dynamic structure which can vary according to the current life circumstances and personal standards.

Life satisfaction (Schmitter, 2003) can be affected by many factors. Happiness in daily life, meanings attributed to life, adaptation to reaching aims, positive personal identity, feeling good physically, finance, security and social relations are among them [22]. Social relations represent an important area which is strongly related with life satisfaction. The underlying reason is that relatives such as husband/wife, kids or friends provide social and financial support as well as sharing free time and being partners [23]. Besides being married or living with a partner, having a social environment also affects life satisfaction in a positive way [24].The relationships with close friends and family members are important too [25]. When the existing literature is reviewed there is not any study which investigates the relationship between the teachers' perceptions regarding life satisfaction and organizational dissent. This piece of study aims to add to the existing literature via finding out the relationship between the teachers' perceptions regarding organizational dissent and life satisfaction.

\subsection{The Aim of the Study}

The aim of this study is to investigate the relationship between primary school teachers' perceptions regarding life satisfaction and organizational dissent. Within this frame the following questions are searched for answers:

Are the Perceptions of Teachers Regarding Organizational Dissent Significantly Meaningful According to;

Gender,

Union Membership,
School Size (the Number of Teachers),

Monthly Income Variables?

Is There a Significant Relationship between the Teachers'

Perceptions Regarding Organizational Dissent and Life

Satisfaction?

\section{Materials and Methods}

This study is in survey and relational survey model. In survey model the person or the object of the study is tried to be determined in its own conditions as it is. In relational survey model, co-change existence and level of change between two or more variables together are investigated [26].

\subsection{Participants}

Study group of this study is composed of 200 primary school teachers (branch teachers excluded) who were chosen randomly among 25 public primary schools which are at the city center of Diyarbakır in 2013-2014 academic year. In determining the school size Jones' [27] classification of the schools is used. According to him; schools which has 28 or less teachers are "small school", 29-39 teachers are "middle schools", 40 and more teachers are "big schools".

\subsection{Data Collection Scales}

The scales used for data collection are presented in the following paragraphs.

Organizational Dissent Scale: In this study "Organizational Dissent Scale" which is developed by Kassing [28] and adapted into Turkish by Dağl1 [4] is used The items in the scale are pointed as "Totally disagree" (1), "Slightly Agree (2), "Agree" (3), "Agree mostly" (4), "Totally Agree" (5). Cronbach Alpha coefficient consistency is found as 0,792 for the "upward dissent" dimension; 0,822 for the "lateral dissent" dimension and 0,849 for the whole of the scale.

Life Satisfaction Scale: "Life Satisfaction Scale" which is developed by Diener, Emmons, Larsen, Griffin (1985) and adapted into Turkish by Dağlı and Baysal [29] is used for data collection in this study. The items in the scale are pointed as "Totally disagree" (1), "Slightly Agree (2), "Agree" (3), "Agree mostly" (4), "Totally Agree" (5). Cronbach Alpha coefficient consistency is found as 0,883 .

\subsection{Data Analysis}

Data of the study are analysis using SPSS 20.0 statistics software. Upwards, standard deviations and levels are calculated to determine the perception levels of teachers regarding the dimension of the organizational dissent and life satisfaction scale. To test if there is a significant relationship between the groups t-test and one way ANOVA is used. To calculate the relationship between the variables Pearson Correlations ( $r$ ) is used. In interpreting the upwards of the 
items in life satisfaction scale "Totally disagree" $(1,00-1,79)$, "Slightly Agree (1,80-2,59), "Agree" (2,60-3,39), "Agree mostly" (3,40-4,19), Totally Agree $(4,20-5,00)$. The significance level is set as 0,05 .

\section{Findings}

In this section, (I) there are findings respectively whether the variables of gender, union membership, school size and total monthly income show a significant difference among the perceptions of teachers about organizational dissent? and (II) whether there is a significant correlation between teachers' perceptions of life satisfaction and organizational dissent.

\subsection{The Evaluation of the Perceptions of the Teachers Regarding Organizational Dissentin Respect to Some Variables}

\subsubsection{Perceptions of Teachers According to Gender}

In order to determine whether there is a significant difference according to gender among the teachers' perceptions of organizational dissent, t-test was used, and the results are given in Table 1.
As seen in Table 1, according to the gender, there is a significant difference among the means of teachers' perceptions of organizational dissent in "upward dissent" dimension; however there is no significant difference in "lateral dissent" dimension. In "upward dissent" dimension, male teachers $(\mathrm{M}=4.14)$ appears to have more dissent than female teachers $(M=3.93)$. In "lateral dissent" dimension there is no significant difference among perceptions of teachers, that upwards the perceptions of male $(M=3.68)$ and female $(M=3.45)$ teachers are close to each other and they have same level of dissent in this dimension.

According to the gender of the teacher, total mean of the perceptions related to "upward dissent" dimension is 4,03 ; for "lateral dissent" is 3,56. This shows that according to the gender, the teachers have dissent at "mostly" level in the dimensions of "upward dissent" and "lateral dissent".

\subsubsection{Perceptions of Teachers According to Union Membership}

In order to determine whether there is a significant difference according to union membership among the teachers' perceptions of organizational dissent, t-test was used, and the results are given in Table 2.

Table 1. T-test results of teachers' perceptions about organizational dissent according to their gender

\begin{tabular}{|c|c|c|c|c|c|c|c|}
\hline Dimension & Gender & $\mathrm{N}$ & $\mathrm{M}$ & SD & $\mathrm{Df}$ & $\mathrm{t}$ & $\mathrm{S}$ \\
\hline \multirow{3}{*}{ Upward Dissent } & Female & 102 & 3,93 & 0,70 & \multirow{3}{*}{198} & \multirow{3}{*}{$-2,21$} & \multirow{3}{*}{$0,028^{*}$} \\
\hline & Male & 98 & 4,14 & 0,65 & & & \\
\hline & Total & 200 & 4,03 & & & & \\
\hline \multirow{3}{*}{ Lateral Dissent } & Female & 102 & 3,45 & 0,84 & \multirow{3}{*}{198} & \multirow{3}{*}{$-1,95$} & \multirow{3}{*}{0,052} \\
\hline & Male & 98 & 3,68 & 0,82 & & & \\
\hline & Total & 200 & 3,56 & & & & \\
\hline
\end{tabular}

${ }^{*} \mathrm{p}<0,05$. Note. N: Number of people, M: Mean, SD: Standard Deviation, Df: Degree of freedom, S: Significance

Table 2. T-test results of teachers' perceptions about organizational dissent according to their union membership

\begin{tabular}{|c|c|c|c|c|c|c|c|}
\hline Dimension & Union Membership & $\mathrm{N}$ & M & SD & Df & $\mathrm{t}$ & $\mathrm{S}$ \\
\hline \multirow{3}{*}{ Upward Dissent } & Yes & 151 & 4,08 & 0,70 & \multirow{2}{*}{198} & \multirow{3}{*}{1,716} & \multirow{3}{*}{0,088} \\
\hline & No & 49 & 3,89 & 0,60 & & & \\
\hline & Total & 200 & 3,98 & & & & \\
\hline \multirow{3}{*}{ Lateral Dissent } & Yes & 151 & 3,69 & 0,83 & \multirow{2}{*}{198} & \multirow{3}{*}{3,691} & \multirow{3}{*}{$0,000^{*}$} \\
\hline & No & 49 & 3,19 & 0,75 & & & \\
\hline & Total & 200 & 3,44 & & & & \\
\hline
\end{tabular}


As seen in Table 2, according to union membership, there is not a significant difference among the means of teachers' perceptions of organizational dissent in "upward dissent" dimension; however, the mean of the perceptions of the teachers who have union membership $(\mathrm{M}=4,08)$ is higher than the teachers' who have no union membership $(M=3,89)$. In "upward dissent" dimension there is no significant difference among perceptions of teachers, that upwards the perceptions of teachers who have union membership and those who have not union membership are close to each other and they have same level of dissent in this dimension.

In "lateral dissent" dimension there found a significant difference among the perceptions of teachers. As seen in the table, the teachers who have union membership $(M=3,69)$ have more dissent than those who have no union membership $(\mathrm{M}=3,19)$. That can be result of the support the teachers get from their unions. According to union membership of the teacher, total mean of the perceptions related to "upward dissent" dimension is 3, 98; for "lateral dissent" is 3, 44. This shows that according to union membership, the teachers have dissent at "mostly" level in the dimensions of "upward dissent" and "lateral dissent".

\subsubsection{Perceptions of Teachers According to School Size}

In order to determine whether there is a significant difference according to school size among the teachers' perceptions of organizational dissent, one way ANOVA was used, and the results are given in Table 3.

As seen in Table 3, according to school size, there is no significant difference among the means of teachers' perceptions of organizational dissent in "upward dissent" and "lateral dissent" dimensions. However, in the dimension "upward dissent" the teachers in the small $(\mathrm{M}=4,04)$ and medium size schools $(\mathrm{M}=4,04)$ have more dissent than those in the big schools $(\mathrm{M}=4,02)$. That can be result of the fact that the teachers in small and medium sized schools face with their administrators more frequently and they are usually aware of the works of their administrators.

On the other hand, in the dimension "lateral dissent", the teachers in big schools $(\mathrm{M}=3,61)$ have more dissent than those in the small $(M=3,58)$ and medium sized schools $(M=3,42)$. According to the school size of the teachers, total mean of the perceptions related to "upward dissent" dimension is 4,03; for "lateral dissent" is 3,57. This shows that the teachers have dissent at "mostly" level in both dimensions.

\subsubsection{Perceptions of Teachers According to Monthly Income}

In order to determine whether there is a significant difference according to monthly income among the teachers' perceptions of organizational dissent, one way ANOVA was used, and the results are given in Table 4.

Table 3. ANOVA results of teachers' perceptions about organizational dissent according to their school size

\begin{tabular}{|c|c|c|c|c|c|c|c|c|c|c|}
\hline Dimensions & Number of Teachers & $\mathrm{N}$ & M & SD & Source of Variance & SS & Df & MS & $\mathrm{F}$ & S \\
\hline \multirow{4}{*}{ Upward Dissent } & Small School & 67 & 4,04 & 0,59 & Between- groups & 0,017 & 2 & 0,008 & \multirow{4}{*}{0,018} & \multirow{4}{*}{0,983} \\
\hline & Medium School & 34 & 4,04 & 0,70 & Inter- groups & 93,49 & 97 & 0,475 & & \\
\hline & Big School & 99 & 4,02 & 0,73 & Total & 93,50 & 99 & & & \\
\hline & Total & 200 & 4,03 & 0,68 & & & & & & \\
\hline \multirow{4}{*}{ Lateral Dissent } & Small School & 67 & 3,58 & 0,73 & Between- groups & 0,95 & 2 & 0,475 & \multirow{4}{*}{0,666} & \multirow{4}{*}{0,515} \\
\hline & Medium School & 34 & 3,42 & 0,92 & Inter- groups & 140,6 & 97 & 0,714 & & \\
\hline & Big School & 99 & 3,61 & 0,88 & Total & 141,5 & 99 & & & \\
\hline & Total & 200 & 3,57 & 0,84 & & & & & & \\
\hline
\end{tabular}

Note. N: Number of people, M: Mean, SD: Standard Deviation, SS: Sum of Sugure, Df: Degree of freedom, MS: Mean of Squares, S: Significance.

Table 4. ANOVA results of teachers' perceptions about organizational dissent according to their monthly income

\begin{tabular}{|c|c|c|c|c|c|c|c|c|c|c|c|}
\hline Dimension & Income & $\mathrm{N}$ & M & SD & $\begin{array}{l}\text { Source of } \\
\text { Variance }\end{array}$ & SS & Df & MS & $\mathrm{F}$ & $\mathrm{S}$ & Significant difference \\
\hline \multirow{6}{*}{$\begin{array}{l}\text { Upward } \\
\text { Dissent }\end{array}$} & 2000-2999 TL & 67 & 4,00 & 0,70 & Between groups & 0,668 & 4 & 0,167 & \multirow{6}{*}{0,351} & \multirow{6}{*}{0,843} & \\
\hline & 3000-3999 TL & 33 & 4,16 & 0,68 & Inter- groups & 92,838 & 195 & 0,476 & & & \\
\hline & 4000-4999 TL & 38 & 4,00 & 0,68 & Total & 93,506 & 199 & & & & \\
\hline & 5000-5999 TL & 45 & 4,00 & 0,73 & & & & & & & \\
\hline & $6000+\mathrm{TL}$ & 17 & 4,06 & 0,49 & & & & & & & \\
\hline & Total & 200 & 4,03 & 0,68 & & & & & & & \\
\hline \multirow{6}{*}{$\begin{array}{l}\text { Lateral } \\
\text { Dissent }\end{array}$} & 2000-2999 TL & 67 & 3,66 & 0,80 & Between- groups & 7,835 & 4 & ,959 & \multirow{6}{*}{2,856} & \multirow{6}{*}{$0,025^{*}$} & \multirow{6}{*}{$\begin{array}{c}\text { Between } \\
\text { 2000-2999TL and } \\
6000+\mathrm{TL}\end{array}$} \\
\hline & 3000-3999 TL & 33 & 3,53 & 0,80 & Inter- groups & 133,716 & 195 & 0,686 & & & \\
\hline & 4000-4999 TL & 38 & 3,60 & 0,84 & Total & 141,551 & 199 & & & & \\
\hline & $5000-5999 \mathrm{TL}$ & 45 & 3,66 & 0,80 & & & & & & & \\
\hline & $6000+\mathrm{TL}$ & 17 & 2,94 & 0,96 & & & & & & & \\
\hline & Total & 200 & 3,57 & 0,84 & & & & & & & \\
\hline
\end{tabular}


As seen in Table 4, according to monthly income, there is no significant difference among the mean of teachers' perceptions of organizational dissent in "upward dissent" dimension, but there is a significant difference in "lateral dissent" dimension $[\mathrm{p}=0,025]$. According to the Scheffé test results applied to determine the significant difference between groups, there is a significant difference between the teachers who have 2000-2999 TL (Turkish Liras) monthly income and those who have $6000 \mathrm{TL}$ and more. It is seen from the arithmetic means that the mean of the perceptions of the teachers having 2000-2999 TL monthly income $(M=3,66)$ is higher than the mean of the teachers having $6000 \mathrm{TL}$ and more $(M=2,94)$. That means the teachers having lower income (2000-2999 TL) have more dissent than those having more income (6000 TL and more) in "lateral dissent" dimension.

\subsection{Related to the Significant Correlation between the Perceptions of Teachers' Organizational Dissent and Life Satisfaction}

The correlation between the perceptions of teachers related to organizational dissent and their perceptions related to life satisfaction is given in Table 5 .

Table 5. The correlation between the perceptions of teachers related to organizational dissent and life satisfaction

\begin{tabular}{|c|c|c|c|c|}
\hline \multicolumn{2}{|c|}{} & $\begin{array}{c}\text { Upward } \\
\text { Dissent }\end{array}$ & $\begin{array}{c}\text { Lateral } \\
\text { Dissent }\end{array}$ & $\begin{array}{c}\text { Organizational } \\
\text { Dissent }\end{array}$ \\
\hline \multirow{3}{*}{$\begin{array}{c}\text { Life } \\
\text { Satisfaction }\end{array}$} & $\mathrm{r}$ & $-0,053$ & $-0,248$ & $-0,181$ \\
\cline { 2 - 5 } & $\mathrm{p}$ & 0,045 & 0,000 & 0,010 \\
\cline { 2 - 5 } & $\mathrm{n}$ & 200 & 200 & 200 \\
\hline
\end{tabular}

As seen in the Table 5, there is a low level, negative, significant correlation between the dimension of "upward dissent" and life satisfaction $[r=-0,053(p=0,045)]$. There is a low, negative, significant correlation between the dimension of "lateral dissent" and life satisfaction $[\mathrm{r}=-0,248$ $(\mathrm{p}=0,000)]$. In total, there is a low, negative, significant correlation between the perceptions of teachers related to organizational dissent and life satisfaction $[\mathrm{r}=-0,181$ $(p=0,010)]$. Therefore, though a low correlation, it can be claimed that as organizational dissent increases life satisfaction decreases and vice versa.

\section{Conclusion and Recommendations}

In this part, the results of the research were examined and the studies in literature regarding to the research subjects were discussed in relation to the results in other studies. Then, some recommendations related to the results are presented for practitioners and researches.

\subsection{Conclusions}

The aim of this study is to examine the correlation between public primary school teachers' perceptions related to organizational dissent and life satisfaction. In the study, the results related to the teachers' perceptions of organizational dissent and life satisfaction were investigated in the literature and discussed in their context.

According to gender, there is a significant difference among the means of the perceptions of teachers in "upward dissent" dimension; however, there is no significant difference in "lateral dissent" dimension. Male teachers $(M=4,14)$ were found to have more dissent then female teachers $(\mathrm{M}=3,93)$ in "upward dissent" dimension. That means the male teachers speak to their administrators directly or indirectly about some organizational policies and applications in which they have different viewpoints. The reason of the male teachers' having more dissent in this dimension may stem from the fact that they have more work options than female teachers. "Those who have the opportunities of finding job easily (Farell and Rusbult, 1992; Rusbult and Lowery, 1985) feel themselves more free and as a result of this do not hesitate to speak out their oppositional views" [30]. Moreover, it was found that those who feel themselves powerless in the organization and want to be out of the conflicts hesitate showing dissent behaviors [14].

On the other hand, according to the gender of the teacher, total mean of the perceptions related to "upward dissent" dimension is 4,03; for "lateral dissent" is 3,56. This shows that according to the gender, the teachers have dissent at "mostly" level in the dimensions of "upward dissent" and "lateral dissent". As it is seen the teachers have more dissent in "upward dissent" dimension. "A factor that plays role in upward dissent behaviors is the fact that the members of organizations having a long-term employment (Cannings, 1992) security in the current workplace" [30]. Since the teachers in state schools know they will work in that job for a long time unless extreme occasions, they do not hesitate to discuss their dissent opinion with their administrators. Redding [2] "states that dissent may be caused by many reasons The most important of them is poor decisions taken by the organization administrator, and those decisions may be illegal and unethical or unproductive, useless and in a manner that angered members of the organization". Therefore, school administrators should be sensitive about adding teachers into decisions at the matters that concern them.

According to union membership, there is not a significant difference among the mean of teachers' perceptions of organizational dissent in "upward dissent" dimension; however, the mean of the perceptions of the teachers who have union membership $(M=4,08)$ is higher than the teachers' who have no union membership $(M=3,89)$. In "upward dissent" dimension, there is no significant difference among perceptions of teachers, that means the perceptions of teachers who have union membership and those who have not union membership are close to each other and they have same level of dissent in this dimension. 
On the other hand Ağalday, Özgan and Arslan [31] state that some teachers tend to transmit various attitudes and behaviors of their administrators to their union; the teachers especially dissent to their administrators through unions in which they are members, however, many teachers do not report out negative experiences lived in school because of the fear of having suffer, and according to the administrators some teachers prefer the strategy of displaced dissent. Displaced dissent strategy occurs when members of the organization choose to transfer the dissenting opinion to those outside the organization. Those outside the organization consist of friends outside the organization members, spouses, partners and family members $[3,9,14]$.

There found a significant difference among the perceptions of the teachers in "lateral dissent" dimension. In that dimension, the teachers who have union membership $(M=3,69)$ have more dissent than those who do not have membership $(M=3,19)$. Lateral dissent consists when members of the organization speak their dissenting views to those members who have no impact on organization balances Members of the organization using the lateral dissent strategy in a way feel themselves safe in their organizations. The members of the organization share their dissenting views as soon as they find someone to listen to them within the organization [9], and members of the organization showing the lateral dissent behaviors are intensely expressed dissent behaviors in cases where their benefits have been damaged [3]. Therefore, these differences in the dimension of "lateral dissent" may result from the fact that the teachers who have union membership trust on their unions and those who are also the members of their union in the same organization, and they come together with them to create power.

According to school size, there is no significant difference among the mean of teachers' perceptions of organizational dissent in "upward dissent" and "lateral dissent" dimensions. However, in the dimension "upward dissent" the teachers in the small $(\mathrm{M}=4,04)$ and medium size schools $(M=4,04)$ have more dissent than those in the big schools $(M=4,02)$. That can be result of the fact that the teachers in small and medium sized schools face with their administrators more frequently and they are usually aware of the works of their administrators. On the other hand, in the dimension of "lateral dissent", the teachers in big schools $(M=3,61)$ have more dissent than those in the small $(M=3,58)$ and medium sized schools $(M=3,42)$. In the similar studies conducted by Dağlı and Ağalday [32, 33, 34] there was not found a significant difference among the perceptions of teachers according to the school size. Related researches also support the findings of this research. According to monthly income, there is no significant difference among the mean of teachers' perceptions of organizational dissent in "upward dissent" dimension, but there is a significant difference in "lateral dissent" dimension $[p=0,025]$. According to the Scheffé test results applied to determine the significant difference between groups, there found a significant difference between the teachers who have 2000-2999 TL monthly income and those who have $6000 \mathrm{TL}$ and more. It is seen from the arithmetic means that the mean of the perceptions of the teachers having 2000-2999 TL monthly income $(\mathrm{M}=3,66)$ is higher than the mean of the teachers having $6000 \mathrm{TL}$ and more $(M=2,94)$. That means the teachers having lower income (2000-2999 TL) have more dissent than those having higher income (6000 TL and higher) in "lateral dissent" dimension. Since the teachers having low income have little more economical problems than those having medium and more income, they may request additional courses for extra tuition fee from the school administration. They may have dissent because of the school's failure to meet these needs. "Lateral dissent consists when members of the organization speak their dissenting views to the members who have no impact on organization balances" [9]. As stated before, the organization members perform lateral dissent behaviors when their benefits have damaged [3]. In some cases, members of the organization do not express their views openly for fear of damaging their benefits though they dissent some applications and policies. That may cause the members of the organization to remain silent or to tell dissenting opinions to the other members of the organization [12]. In order to prevent the dissent among the teacher groups their salaries and wages should be improved and the administrators should do positive discrimination for the teachers with low income in financial issues.

There found a low level, negative, significant correlation between the dimension of "upward dissent" and life satisfaction $[\mathrm{r}=-, 053(\mathrm{p}=0,045)]$. There found a low, negative, significant correlation between the dimension of "lateral dissent" and life satisfaction $[\mathrm{r}=-, 248(\mathrm{p}=0,000)]$. In total, there is a low, negative, significant correlation between the perceptions of teachers related to organizational dissent and life satisfaction $[\mathrm{r}=-, 181$ $(p=0,010)]$. Therefore, though a low correlation, it can be claimed that as organizational dissent increases life satisfaction decreases and vice versa. Therefore, life satisfaction should be increased at the same time organizational dissent should be decreased. Gemma (2007) put forward many reasons that push teachers to dissent. Some of them of are listed as follows: inconvenient educational environments, inadequate resources allocated to education, overly bureaucratic and centralized organizational structure, and partisan attitudes applied in the appointment of teachers [30]. Kassing [9] also stated that organizational dissent may occur as a result of organizational conflicts and when the administrators do not include the members to the organizational decisions "Getting the ideas of members, sharing the reasons of the decisions can increase their confidence in organizational managers. Thus, the perception of justice in the organization will be positively affected" [35]. Therefore, managers should necessarily take teachers into decisions in 
matters that concern them. The teachers should be given the opportunity of questioning the decisions, decisions regarding teachers should be discussed with all the necessary grounds and teachers must be informed in time. On the other hand, Appleton and Song (2008) stated six different components of life satisfaction; (1) the person's income, (2) professional and social status, (3) opportunities and social mobility, (4) welfare conditions, (5) the current state policy and (6) the environment, family and social relationships [36]. Schmitt (2003) claimed that individual life satisfaction may be affected by a lot of conditions such as; happiness taken from daily life, the means attributed to life, consistency in reaching the goal, positive personal identity, individual feel of physically welfare, economic, security and the social relations [22]. It is stated that (Marques, et al, 2007) high life satisfaction for adults has positive outcomes for interpersonal relations, one's own inner world, business, physical and psychological health and educational status [37].

\subsection{Recommendations}

Based on the research findings, the following recommendations are asserted: (1) During the in-service teacher training courses organized by Ministry of National Education the issues related to life satisfaction and organizational dissent should be focused. (2) Administrators absolutely should take the teachers in decisions concerning them. It should be given the opportunity to question the decisions if needed. Teachers must be informed about all the necessary decisions with their reasons in time. (3) School administrators should give adequate importance to the development of democratic processes in the school (4) Administrator should not forget if they are unable to manage the dissent process effectively, they will face that dissent behaviors. Therefore, the Ministry of Education should organize in-service training courses to develop communication competencies of managers and in order to make them effective in dissent management. (5) The solutions regarding the incident which caused the dissent exhibited by teachers as an indicator of democracy in school must be taken into account by managers. (6) According to the monthly income of teachers there was found to be significant differences in the perception of the "lateral dissent" dimension. There is significant difference between the perceptions of teachers who have 2000-2999 monthly income and those who have 6000 and high. In order to prevent the dissent between these teacher groups their salaries and wages should be improved and the administrators should do positive discrimination for the teachers with low income in financial issues. (7) Factors affecting the future expectations of teachers negatively should be investigated more deeply and measures must be taken to enable them to be optimistic about the future. (8) Life satisfaction approach helps achieving both organizational and individual objectives. To improve life satisfaction in the schools, positive communication philosophy should be adopted and expanded. The basic approach of this philosophy must be designing the organizational communication structure in a way to meet the individual needs. (9) Giving detailed information to the teachers about the school, work and performance will improve their business performance as well as increase their life satisfaction. (10) The schools have adopted the approach of life satisfaction should create a democratic and supportive work environment. (11) Legal regulation should be done to employ psychologists in the schools to increase the life satisfaction of the employees of schools.

In this study, teachers' perceptions of life satisfaction and organizational dissent were investigated; similar research may be conducted on perceptions of non-teaching employees. Similar studies may be done in public and private secondary schools in both quantitative and qualitative methods. Also the relationship between organizational dissent and job satisfaction, organizational citizenship, engaging to the work, and burnout may be examined.

\section{REFERENCES}

[1] TDK. (1998). TürkçeSözlük. Ankara: TDK Yayınları.

[2] Redding, W. C. (1985). Rocking boats, blowing whistles, and teaching speech communication. Communication Education, 34, 245-258.

[3] Kassing, J. W. (1997. Articulating, antagonizing and displacing: A model of employee dissent. Communication Studies, 48 (4), 311-332.

[4] Dağl1, A. (2015). Örgütsel Muhalefet Ölçeği'nin Türkçe' ye uyarlanması: Geçerlik ve güvenirlik çalışması. Elektronik Sosyal Bilimler Dergisi (Electronic Journal of Social Sciences), 14 (53), 198-218.

[5] Hegstrom, T. G. (1991). Mimetic and dissent conditions in organizational rhetoric. Journal of Applied Communication Research, 18 (2), 141-152.

[6] Graham, J. W. (1986). Principle organizational dissent: A Theoretical essay. Researching Organizational Behavior, 8, $1-52$.

[7] Kassing, J. W. \& Armstrong, T. A. (2002). Someone's going to hear about this: Examining the association between dissent-triggering events and employee's dissent expressions. Management Communication Quarterly, 16 (39), 39-65.

[8] Kassing, J. W. (2002). Speaking up: Identifying employees' upward dissent strategies. Management Communication Quarterly, 16 (2), 187:209.

[9] Kassing, J. W. (1998). Development and validation of the organizational dissent scale. Management Communication Quarterly, 12 (2), 183-229.

[10] Kassing. J W. \& Avtgis, T. A. (1999). Examining the relationship between organizational dissent and aggressive 
communication. Management Communication Quarterly, 13 (100), 76-91.

[11] Kassing, J. W. (2009). Investigating the relationship between superior-subordinate relationship quality and employee dissent. Communication Research Reports, 17 (1), 58-69.

[12] Kassing, J. W. \& Avtgis, T. A. (2009). Dissension in the organization as a function of control expectancies. Communication Research Reports, 18, 118-127.

[13] Kassing, J. W. \& Armstrong, T. A. (2009). Examining the association of job tenure, employment history and organizational status with employee dissent. Communication Research Reports, 18, 264-273.

[14] Kassing, J. W. (2001). From the looks of things: Assessing perceptions of organizational dissenters. Management Communication Quarterly, 14 (3), 442-470.

[15] Haybron, D. M. (2004). Happiness and the importance of life satisfaction. Delivered at the Department of Philosophy. University of Arizona.

[16] Diener, E., Emmons, R. A., Larsen, R. J. \& Griffin, S. (1985). The satisfaction with life scale. Journal of Personality Assessment, 49 (1), 71-75.

[17] Rice, R. W., Frone, M. R. \& McFarlin, D. B. (1992) Work-Nonwork Conflict and the Perceived Quality of Life. Journal of Organizational Behavior, 13 (2), 155-168.

[18] Veenhoven, R. (1996a). Chapter 1 In: W E Saris, R Veenhoven, A C Scherpenzeel, B Bunting (Eds.): A Comparative Study of Satisfaction with Life In Europe. Eötvös University Press, 2, 11-48.

[19] Veenhoven, R. (1996b). Happy life-expectancy: A comprehensive measure of quality-of-life in nations. Social Indicators Research, 39, 1-58

[20] Myers, D. G. \& Diener, E. (1995). Who is happy? Psychological Science, 6 (2), 10-16.

[21] Diener, E. (1984). Subjective well-being. Psychological Bulletin, 95 (3), 542-575.

[22] Y1lmaz, E. \&Aslan, H. (2013). Öğretmenlerin iş yerindeki yalnızlık ları ve yaşam doyumları arasındaki ilișkinin incelenmesi. Pegem Ĕgitim ve Öğretim Dergisi, 3 (3), 59-69.

[23] Adams, D. L. (1971). Correlates of satisfaction among the elderly. Gerontologist, (11), 64-68.

[24] Diener, E., Gohm, C., Suh, E. \& Oishi, S. (2000). Similarity of the relations between marital status and subjective well-being across cultures. Journal of Cross-Cultural Psychology, 31 (4), 419-436.
[25] Diener, M. L. \& Diener McGavran, M. B. (2008). What makes people happy? A developmental approach to the literature on family relationships and well-being. In R Larson, M Eid (Eds.), The science of subjective well-being. New York: Guilford (pp. 347-375).

[26] Karasar, N. (2006). Bilimsel Araştırma Yöntemleri. Ankara: Nobel Yayınları.

[27] Jones, R. E. (1997). Teacher participation in decision making-1ts relationship to staff morale and students achievement. Education, 118 (1), 76-83.

[28] Kassing, J. W. (2000). Investigating the relationship between superior-subordinate relationship quality and employee dissent. Communication Research Reports, 17 (1), 58-69.

[29] Dağl1, A. \&Baysal, N. (2016). Yaşam doyum ölçeğİIİn Türkçe'ye uyarlanması: Geçerlík ve güvenİlİk çalişmasi. Elektronik Sosyal Bilimler Dergisi (Electronic Journal of Social Sciences), 15 (59), 1250-1262.

[30] Özdemir, M. (2010). Ankara ili kamu genel liselerinde görev yapan yönetici ve öğretmenlerin örgütsel muhalefete ilişkin görüşleri. Yayınlanmamış doktora tezi, Ankara Üniversitesi, Eğitim Bilimleri Enstitüsü.

[31] Ağalday, B., Özgan, H. \&Arslan, M. C. (2014). İlkokul ve Ortaokullarda Görevli Yöneticilerin Örgütsel Muhalefete ilișkin algıları. Pegem Ĕgitim ve Öğretim Dergisi, 4 (3), 35-50.

[32] Dağl1, A. \& Ağalday, B. (2014a). Öğretmenlerİn örgütsel muhalíf davraniş bİçİmlerİne İlİşkİn görüşlerİ. Elektronik Sosyal Bilimler Dergisi (Electronic Journal of Social Sciences), 13 (50), 112-128

[33] Dağl1, A. \& Ağalday, B. (2014b). Öğretmenlerİn örgütsel muhalefetİn sonuçlarina İlİşkİn görüşlerİ.Akademik Sosyal Araştırmalar Dergisi, (2/1), 170-182

[34] Dağlı, A. \& Ağalday, B. (2015). Öğretmenlerin örgütsel muhalefetin nedenlerine İlişkin görüşleri. İlköğretim Online, 14 (3), 885-898.

[35] Söyük, S. (2007). Örgütsel adaletin iş tatmini üzerine etkisi ve İstanbul ilindeki özel hastanelerde çalıșan hemşirelere yönelik bir çalışma. Yayınlanmamış doktora tezi İstanbul Üniversitesi, Sosyal Bilimler Enstitüsü.

[36] Appleton, S. \& Song, L. (2008). Life satisfaction in urban China: Components and determinants. World Development, 36 (11), 2325-2350

[37] Bekmezci, M. \&Mert, S. (2013). Yaşam doyumu ölçeğinin türkçe'ye uyarlanması: geçerlik ve güvenirlik çalışması. I.Örgütsel Davranış Kongresi Bildiriler Kitabı. Sakarya Üniversitesi İșletme Fakültesi. 